\title{
Pancreatic fibroblasts smoothen their activities via AKT-GLI2-TGFa
}

\author{
Anil K. Rustgi \\ Division of Gastroenterology, Department of Medicine, Department of Genetics, Abramson Cancer Center, University \\ of Pennsylvania Perelman School of Medicine, Philadelphia, Pennsylvania 19104, USA
}

Pancreatic stromal fibroblasts provide structural support. Activated fibroblasts are critical in the tumor microenvironment. In this issue of Genes \& Development, Liu and colleagues (pp. 1943-1955) unravel the finding that depletion of Smoothened (Smo) in pancreatic stromal fibroblasts results in AKT activation and noncanonical GLI2 activation with subsequent TGFa secretion, activation of EGFR in pancreatic epithelial cells, and augmentation of acinar-ductal metaplasia. Additionally, Smo-mediated signaling has proproliferative effects on pancreatic tumor cells.

Fibroblasts contribute to the structural integrity of the mesenchyme in part through the production of extracellular matrix proteins and collagen. Maintained in a quiescent state during homeostasis, fibroblasts may become activated during a variety of processes, such as inflammation, wound healing, and cancer. Activated fibroblasts demonstrate a different morphological identity and are annotated by markers such as vimentin, smooth muscle actin (SMA), fibroblast-activation protein (FAP), fibroblast-secreting protein (FSP), N-cadherin, and others. Furthermore, activated fibroblasts are known to secrete a variety of growth factors, cytokines, and chemokines that display both autocrine and paracrine effects-the latter on tumor cells but also inflammatory cells, immune cells, and blood vessels.

Certain cancers are highlighted by dense growth of connective tissue, referred to as desmoplasia. Striking examples are evident in esophageal cancer and pancreatic ductal adenocarcinoma (PDAC). Long felt to be permissive for tumor cell migration and invasion, the dichotomous nature of desmoplasia is being appreciated recently as harboring tumor-restraining properties related to Hedgehog signaling or cancer-associated fibroblasts (CAFs) (Lee et al. 2014; Özdemir et al. 2014; Rhim et al. 2014). To that end, pharmacological inhibition or genetic depletion of Hedgehog signaling or genetic depletion of CAFs results

[Keywords: acinar-to-ductal metaplasia; hedgehog signaling; EGFR signaling; stromal fibroblast; AKT signaling]

Corresponding author: anil2@mail.med.upenn.edu

Article is online at http://www.genesdev.org/cgi/doi/10.1101/gad.289272. 116. in reduced desmoplasia but favors tumor cell survival and dissemination.

A deep appreciation of the biological behavior of fibroblasts in PDAC has evolved with initial insights gained through studies of the pancreatic epithelium. One critical component is the Hedgehog pathway, already established to be important in the repression of pancreatic organogenesis (Hebrok et al. 1998; 2000). Pancreata of Pdx-Shh mice harbor abnormal tubular structures reminiscent of human pancreatic intraepithelial neoplasia 1 (PanIN-1) and PanIN-2 (Thayer et al. 2003). When hedgehog signaling is activated in the pancreatic epithelium of transgenic mice, there is the emergence of undifferentiated carcinomas (Pasca di Magliano et al. 2006). This group also found that concurrent activation of KRAS and Hedgehog signaling causes robust PanIN formation and accelerates mortality, thereby raising the specter of cooperation between KRAS and Hedgehog in pancreatic ductal epithelial cells and subsequent Smoothened (SMO) activation in fibroblasts. Insights into this were gained through the genetic finding in mice that Gli transcription is not linked to Shh-Ptch-Smo signaling and is regulated by TGF $\beta$ and KRAS (Nolan-Stevaux et al. 2009). Furthermore, Gli is needed for the KRAS-mediated transformed phenotype in PDAC cells (Nolan-Stevaux et al. 2009).

In the current study by Liu et al. (2016), the investigators sought to elucidate how Hedgehog signaling from pancreatic stromal fibroblasts impacts pancreatic acinar-ductal metaplasia (ADM), which is a consequence of cellular plasticity in response to injury (e.g., cerulein-induced acute pancreatitis in mice) and is governed by a set of transcriptional factors, such as Sox9, Prrx1, Mist1, and Ptfla (Reichert et al. 2013). ADM has been established in mice to be a precursor of PanIN and PDACs. The investigators ablated Smo in the fibroblasts of $\mathrm{Kras}^{\mathrm{G12D}}$ mice, resulting in increased ADM. This was found to be due to increased TGFa secretion from the fibroblasts and activation of EGFR signaling in acinar cells-the latter known to be an upstream regulator of ADM. Within the

C 2016 Rustgi This article is distributed exclusively by Cold Spring Harbor Laboratory Press for the first six months after the full-issue publication date (see http://genesdev.cshlp.org/site/misc/terms.xhtml). After six months, it is available under a Creative Commons License (Attribution-NonCommercial 4.0 International), as described at http:// creativecommons.org/licenses/by-nc/4.0/. 


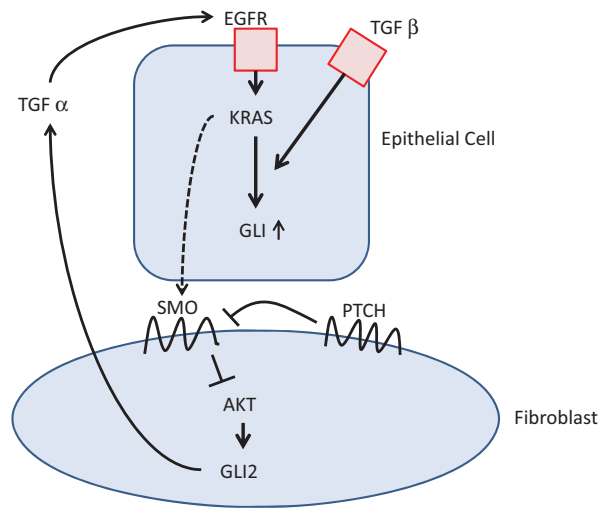

Figure 1. A proposed model of the effects of Hedgehog signaling in pancreatic stromal fibroblasts and epithelial cells.

fibroblasts, Smo deletion results in AKT activation and noncanonical GLI2 activation; interestingly, there is no effect on GLI1 or GLI3. AKT signaling phosphorylates GLI2 Ser230, and this enhances TGFa expression. This may be part of a non-cell-autonomous basis for the regulation of ADM, as other studies have provided evidence for cell-autonomous regulation of ADM mediated through a combination of EGFR signaling, Notch signaling, of course KRAS activation, and the aforementioned transcriptional factors. Nonepithelial effects are observed as well with Smo ablation in fibroblasts, including increased angiogenesis, decreased CD3-positive T-cell infiltration, and increased FoxP3-positive $\mathrm{T}$ regulatory cell infiltration, suggesting effects on the microenvironment.

The effects of Smo-deleted fibroblasts are not restricted to ADM, although regulation of ADM was the primary intent of the study. Smo-mediated signaling has proproliferative effects on KPC tumor cells. Coinjection of a KPC tumor cell line with Smo-deleted fibroblasts augments tumor burden when compared with coinjection with Smointact fibroblasts.

Overall, Hedgehog signaling has diverse and complex effects on pancreatic epithelial cells versus pancreatic stromal fibroblasts and helps to explain its impact on ADM, PanIN, and PDAC (Fig. 1). Targeting Hedgehog signaling is not a simple matter and may require combinatorial approaches with VEGFR antibody, as suggested recently (Rhim et al. 2014). The current study raises the possibility that Hedgehog signaling inhibition in concert with AKT inhibition (stromal fibroblasts) may be beneficial or Hedgehog signaling inhibition with EGFR inhibition as well (pancreatic epithelial cells), although EGFR inhibition alone has not proven efficacious in PDAC patients.

\section{References}

Hebrok M, Kim SK, Melton DA. 1998. Notochord repression of endodermal Sonic hedgehog permits pancreas development. Genes Dev 12: 1705-1713.

Hebrok M, Kim SK, St-Jacques B, McMahon AP, Melton DA. 2000. Regulation of pancreas development by hedgehog signaling. Development 127: 4905-4913.

Lee JJ, Perera RM, Wang H, Wu DC, Liu XS, Han S, Fitamant J, Jones PD, Ghanta KS, Kawano S, et al. 2014. Stromal response to Hedgehog signaling restrains pancreatic cancer progression. Proc Natl Acad Sci 111: E3091-E3100.

Liu X, Pitarresi JR, Cuitiño MC, Kladney RD, Woelke SA, Sizemore GM, Nayak SG, Egriboz O, Schweickert PG, Yu L, et al. 2016. Genetic ablation of Smoothened in pancreatic fibroblasts increases acinar-ductal me Ltaplasia. Genes Dev (this issue). doi: 10.1101/gad.283499.116.

Nolan-Stevaux O, Lau J, Truitt ML, Chu GC, Hebrok M, Fernández-Zapico ME, Hanahan D. 2009. GLI1 is regulated through Smoothened-independent mechanisms in neoplastic pancreatic ducts and mediates PDAC cell survival and transformation. Genes Dev 23: 24-36.

Özdemir BC, Pentcheva-Hoang T, Carstens JL, Zheng X, Wu CC, Simpson TR, Laklai H, Sugimoto H, Kahlert C, Novitskiy SV, et al. 2014. Depletion of carcinoma-associated fibroblasts and fibrosis induces immunosuppression and accelerates pancreas cancer with reduced survival. Cancer Cell 25: 719-734.

Pasca di Magliano M, Sekine S, Ermilov A, Ferris J, Dlugosz AA, Hebrok M. 2006. Hedgehog/Ras interactions regulate early stages of pancreatic cancer. Genes Dev 20: 3161-3173.

Reichert M, Takano S, von Burstin J, Kim SB, Lee JS, Ihida-Stansbury K, Hahn C, Heeg S, Schneider G, Rhim AD, et al. 2013. The Prrx 1 homeodomain transcription factor plays a central role in pancreatic regeneration and carcinogenesis. Genes Dev 27: 288-300.

Rhim AD, Oberstein PE, Thomas DH, Mirek ET, Palermo CF, Sastra SA, Dekleva EN, Saunders T, Becerra CP, Tattersall IW, et al. 2014. Stromal elements act to restrain, rather than support, pancreatic ductal adenocarcinoma. Cancer Cell 25: 735-747.

Thayer SP, di Magliano MP, Heiser PW, Nielsen CM, Roberts DJ, Lauwers GY, Qi YP, Gysin S, Fernández-del Castillo C, Yajnik $\mathrm{V}$, et al. 2003. Hedgehog is an early and late mediator of pancreatic cancer tumorigenesis. Nature 425: 851-856. 


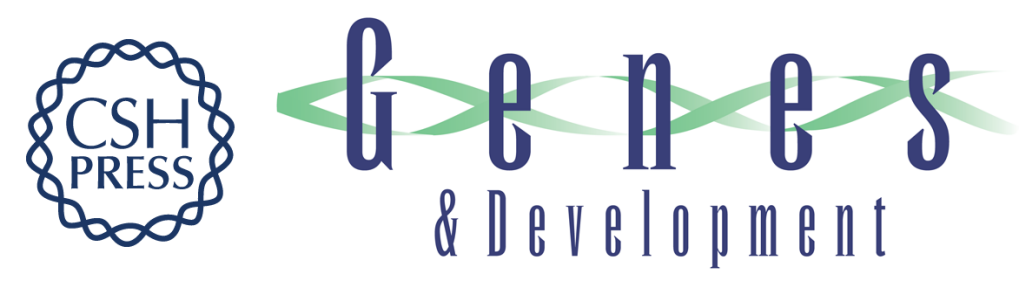

\section{Pancreatic fibroblasts smoothen their activities via AKT-GLI2-TGF $\alpha$}

Anil K. Rustgi

Genes Dev. 2016, 30:

Access the most recent version at doi:10.1101/gad.289272.116

\section{Related Content Genetic ablation of Smoothened in pancreatic fibroblasts increases acinarductal metaplasia \\ Xin Liu, Jason R. Pitarresi, Maria C. Cuitiño, et al. \\ Genes Dev. September, 2016 30: 1943-1955}

References This article cites 10 articles, 7 of which can be accessed free at:

http://genesdev.cshlp.org/content/30/17/1911.full.html\#ref-list-1

Articles cited in:

http://genesdev.cshlp.org/content/30/17/1911.full.html\#related-urls

Creative This article is distributed exclusively by Cold Spring Harbor Laboratory Press for the first Commons

License

six months after the full-issue publication date (see

http://genesdev.cshlp.org/site/misc/terms.xhtml). After six months, it is available under a Creative Commons License (Attribution-NonCommercial 4.0 International), as described at http://creativecommons.org/licenses/by-nc/4.0/.

Email Alerting

Receive free email alerts when new articles cite this article - sign up in the box at the top

Service

right corner of the article or click here.

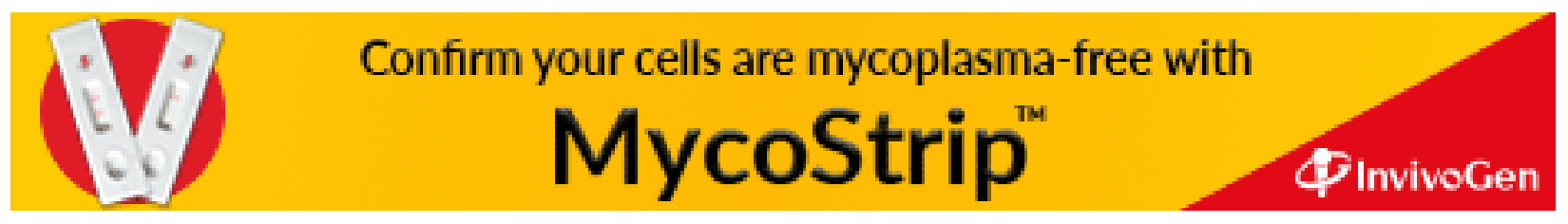

